\title{
Aesthetic and sensory quality of Emerald grass (Zoysia japonica) as a function of substrate cultivation and mineral fertilization
}

\author{
Patrick Luan Ferreira dos Santos ${ }^{1 *}$, Philippe Solano Toledo Silva ${ }^{1}$ (]), \\ Aline Marchetti Silva Matos² (1), Maria Luana Alves ${ }^{3}$ (1), \\ Matheus Vinícios Leal do Nascimento ${ }^{1}\left(\mathbb{0}\right.$, Regina Maria Monteiro de Castilho ${ }^{4}$ (D)
}

\begin{abstract}
${ }^{1}$ Universidade Estadual Paulista (UNESP), Faculdade de Ciências Agronômicas, Botucatu-SP, Brazil. ${ }^{2}$ Universidade Estadual Paulista (UNESP), Faculdade de Ciências Agrárias e Tecnológicas, Dracena-SP, Brazil. ${ }^{3}$ Universidade de São Paulo (USP), Faculdade de Medicina Veterinária e Zootecnia, Pirassununga-SP, Brazil. ${ }^{4}$ Universidade Estadual Paulista (UNESP), Faculdade de Engenharia de Ilha Solteira, Ilha Solteira-SP, Brazil.
\end{abstract}

\begin{abstract}
Ornamental lawns, such as Emerald grass (Zoysia japonica), require adequate fertilization management for their development, as well as the substrate used as a base in cultivation is of great importance to improve the aesthetic quality of the species. These two factors together, can provide a better acceptance of the turfgrass, through sensory analysis. Thus, the objective of this study was to evaluate the aesthetic and sensory quality of the Emerald grass, as a function of cultivation on substrates and mineral fertilization. The work was carried out from September to December 2012, in a $5 \times 3$ factorial scheme [5 substrates x (2 fertilizers + control)], with 3 repetitions. Emerald grass mats were implanted in $8.5 \mathrm{~L}$ containers, filled with 5 substrates: $\mathrm{S} 1=$ soil, S2 $=$ soil + sand $(2: 1)$, $\mathrm{S} 3=$ soil + organic compost $(1: 1), \mathrm{S} 4=$ soil + compost organic + sand $(2: 1: 1)$ and S5 = compost + sand (3:1). And the fertilizers used were based on a NPK formulation (10-10-10) applying $60 \mathrm{~g} \mathrm{~m}^{-2}$, and $125 \mathrm{~g} \mathrm{~m}^{-2}$ of a commercial product. Were evaluated: lawn height, relative chlorophyll index, dark green color index, and sensory analysis for appearance and color attributes and acceptability index. It was observed that the substrates based on organic compost presented the best results for the evaluated parameters, and the fertilizations carried out with the commercial product and the formulated NPK, presented similar results in the grass development evaluations, while the sensorial analysis is an important tool for accepting the aesthetics of a lawn.
\end{abstract}

Keywords: organic compost, ornamental lawn, turfgrass.

\section{Resumo}

Qualidade estética e sensorial da grama esmeralda (Zoysia japonica) em função do cultivo em substratos e adubação mineral Gramados ornamentais, como a grama esmeralda (Zoysia japonica) requerem manejos adequados de adubação para seu desenvolvimento, bem como o substrato utilizado como base no cultivo é de grande importância para melhorar a qualidade estética da espécie. Esses dois fatores juntos, podem propiciar uma melhor aceitação da grama, através de análise sensorial. Assim, o objetivo deste estudo foi avaliar a qualidade estética e sensorial da grama esmeralda, em função do cultivo em substratos e adubação mineral. O trabalho foi desenvolvido de setembro a dezembro de 2012, em esquema fatorial $5 \times 3$ [ 5 substratos $\mathrm{x}$ ( 2 fertilizantes + testemunha)], com 3 repetições. Foram implantados tapetes de grama esmeralda em contêineres de 8,5 L, preenchidos com 5 substratos: S1 = solo, S2 = solo + areia (2:1), S3 = solo + composto orgânico (1:1), S4 = solo + composto orgânico + areia (2:1:1) e S5 = composto + areia (3:1). E os fertilizantes utilizados foram baseados em um formulado de NPK (10-10-10) aplicando $60 \mathrm{~g}$ $\mathrm{m}^{-2}$, e $125 \mathrm{~g} \mathrm{~m}^{-2}$ de um produto comercial. Avaliaram-se a altura do gramado, índice relativo de clorofila, índice de cor verde escuro, e análise sensorial para os atributos aparência e cor, e índice de aceitabilidade. Observou-se que os substratos a base de composto orgânico apresentaram os melhores resultados para os parâmetros avaliados, e as adubações realizadas com o produto comercial e o formulado NPK, apresentaram resultados semelhantes nas avaliações de desenvolvimento da grama, enquanto a analise sensorial é uma importante ferramenta para aceitação da estética de um gramado.

Palavras-chave: composto orgânico, grama ornamental, gramado.

*Corresponding author: patricklfsantos@gmail.com 


\section{Introduction}

Ornamental turfgrass will assume a prominent place in the world, mainly due to their great aesthetic value and diverse functionalities (Santos and Castilho, 2018a). Where, in last years, several species were introduced in Brazil (Godoy et al., 2012), with Emerald grass (Zoysia japonica) being the most commercialized in the country (Mota et al., 2019).

This species is warm season, and has rhizomatous and stoloniferous growth, with leaves of fine to medium texture, with excellent density and green color (Christians et al., 2016; Backes et al., 2017). It has great adaptation to Brazilian conditions, with good resistance to trampling and to different types of soils, being of medium nutritional requirement (Godoy et al., 2012). Thus, due to these characteristics, it has become the most used turfgrass species in landscape architecture (Sampaio, 2012).

However, when ornamental species are used in residential or commercial projects, it is essential to evaluate the effects on the quality of the plant, particularly in relation to the visual aspect, based on analyzes of future consumers (Neves et al., 2018). Thus, sensory perceptions, such as appearance, color and texture must be evaluated (Morris and Shearman, 1998; Santos et al., 2018), as these variables are directly related to the correct management of the lawn (Godoy et al., 2012).

The fertilization of turfgrass, mainly nitrogen, gives intense green color, brightness, greater growth, recovery from injuries and closure of the turfgrass (Mota et al., 2019). Therefore, it is the main nutrient involved in the aesthetic quality of the plant (Oliveira et al., 2018). However, fertilizer information is lacking for the maintenance of ornamental turfgrass in Brazil (Gazola et al., 2019), and research is needed to alleviate this situation. Allied to this, it is necessary the correct use of the materials that will compose the substrate used in the cultivation of the turfgrass, as these must have physical, chemical and biological properties suitable for the establishment and development of the plant (Santos and Castilho, 2015). Where, all these factors listed, influence the sensory characteristics of the plant.

Therefore, the aim of this study was to evaluate the sensory perception of possible consumers, with respect to Emerald grass, grown on substrates and mineral fertilization.

\section{Material and methods}

The experiment was carried out from September 15 to December 22, 2012 (average temperature of $27.6^{\circ} \mathrm{C}$, with average relative humidity of $68.7 \%$ ), in the field, in a $5 \times 3$ factorial scheme [ 5 substrates x (2 fertilizers + control)], with the experimental design being completely randomized with 15 treatments and 3 repetitions each.

The substrates were: $\mathrm{S} 1=$ soil, $\mathrm{S} 2=$ soil + sand $(2: 1)$, $\mathrm{S} 3=$ soil + organic compost (1: 1$), \mathrm{S} 4=$ soil + organic compost + sand (2:1:1) and S5 = compost + sand (3:1). And the fertilizers used were based on a NPK formulation (10-10-10) applying $60 \mathrm{~g} \mathrm{~m}^{-2}$, and $125 \mathrm{~g} \mathrm{~m}^{-2}$ of a commercial product (Table 1), and maintaining the control (without fertilization).

Table 1. Data on the formulation of the commercial product.

\begin{tabular}{|c|c|c|c|c|c|c|c|c|c|c|c|c|c|}
\hline & $\mathbf{N}$ & $\mathbf{C a}$ & $\mathbf{B}$ & $\mathbf{F e}$ & $\mathbf{P}_{\mathbf{2}} \mathbf{O}_{\mathbf{5}}^{*}$ & $\mathbf{M g}$ & $\mathbf{M o}$ & $\mathbf{C u}$ & $\mathbf{K}_{\mathbf{2}} \mathbf{O}^{* *}$ & $\mathbf{S}$ & $\mathbf{M n}$ & $\mathbf{Z n}$ \\
\hline$\%$ & 13.0 & 1.0 & 0.04 & 0.2 & 5.0 & 1.0 & 0.005 & 0.05 & 13.0 & 5.0 & 0.08 & 0.15 \\
\hline
\end{tabular}

*Soluble in CNA + water; **Soluble in water.

For the installation of the experiment, Emerald grass sod of 0,62 $\times 0,45 \mathrm{~m}$ dimensions were used, these being cut and implanted in black plastic containers $(47,5 \times 17,5$ $\mathrm{cm}$ higher measures, $41,5 \times 11,3 \mathrm{~cm}$ lower measurements, height $15,5 \mathrm{~cm}$, volume $8,46 \mathrm{~L}$ ) with the substrates already prepared and allocated inside each container, previously identified. The fertilization was carried out afterwards, with each fertilizer, both of which were spread over the turfgrass, duly identified, and watered afterwards.

To prepare the substrates, the soil used was a Dystropheric Red Latosol removed from the $0-20 \mathrm{~cm}$ layer, under cerrado, in a legal reserve area of an experimental farm. The organic compost was decomposed for one year, being formed from the leaves of Bahia grass (Paspalum notatum) and corral manure (1:1) and the washed medium sand was purchased from local stores.
Weed control was performed whenever necessary, through manual removal. The irrigation management was carried out daily manually, and the containers received water until saturation, in order to ensure that the water factor did not interfere in the results. At the end of the experiment, the following analyzes were performed:

- Height, with the aid of a graduated ruler, placed next to the blade of turfgrass, and height measured, with 5 readings per experimental plot and an average of each treatment;

- Chlorophyll Relative Index - obtained with the help of the Opti-sciences brand Chlorophyll Content Meter (CCM 200), whose measurement unit is CCI (Chlorophyll Content Index), which presents the value proportional to the amount of chlorophyll in the sample;

- Dark green color index, where photographs of the area were taken with a $5 \mathrm{Mp}$ camera, at a distance of 1 , these 
images being transferred to a computer, and with the aid of the Adobe Fireworks ${ }^{\circledR}$ program, the RGB value (Red, Green and Blue) was generated. As only the green (G) component does not define the green color, depending also on the red (R) and blue (B) components, the results were compiled into an electronic spreadsheet in MS Excel and converted to HSB, that is, hue, saturation and brightness, according to the methodology described by Godoy et al. (2012). After obtaining the HSB values, the Dark Green Color Index (DCGI) was calculated (Karcher and Richardson, 2003).
- Sensory analysis: The most significant treatments were separated and placed randomly in a given location. Thus, the perceptions of each possible consumer were recorded on an evaluation form as to the appearance and color attributes, following a hedonic scale of nine points (Chaves and Sproesser, 2005), through an answer sheet (Chart 1) delivered to 40 untrained individuals (20 women and 20 men) between 19 and 52 years old.

Chart 1. Answer sheet with hedonic scale from 1 to 9 points and from 1 to 5 points, used in sensory analysis.

\begin{tabular}{|c|c|c|c|c|c|c|}
\hline $\begin{array}{l}\text { Sensory analysis } \\
\begin{array}{ll}\text { ( ) Male } \quad(\quad) \text { Female }\end{array}\end{array}$ & & $\begin{array}{c}\text { Container } \\
01\end{array}$ & $\begin{array}{c}\text { Container } \\
02\end{array}$ & $\begin{array}{c}\text { Container } \\
03\end{array}$ & $\begin{array}{c}\text { Container } \\
04\end{array}$ & $\begin{array}{c}\text { Container } \\
05\end{array}$ \\
\hline Date: $\_$_ & $\begin{array}{c}\text { Appearance } \\
\text { note: }\end{array}$ & & & & & \\
\hline & Coloring & & & & & \\
\hline You are looking at different containers & note: & & & & & \\
\hline $\begin{array}{l}\text { containing Emerald grass } \\
\text { Evaluate: a) Appearance b) Coloring }\end{array}$ & $\begin{array}{l}\text { Use } \\
\text { note: }\end{array}$ & & & & & \\
\hline that follow: & & & & & & \\
\hline 1 - I really disliked & & Container & Container & Container & Container & Container \\
\hline 2 - I disliked a lot & & 06 & 07 & 08 & 09 & 10 \\
\hline $\begin{array}{l}3 \text { - Disliked moderately } \\
4 \text { - I slightly disliked }\end{array}$ & $\begin{array}{c}\text { Appearance } \\
\text { note: }\end{array}$ & & & & & \\
\hline $\begin{array}{l}5 \text { - Indifferent } \\
6 \text { - I liked it slightly }\end{array}$ & $\begin{array}{l}\text { Coloring } \\
\text { note: }\end{array}$ & & & & & \\
\hline $\begin{array}{l}7 \text { - I liked it moderately } \\
8 \text { - I liked it very much }\end{array}$ & $\begin{array}{l}\text { Use } \\
\text { note: }\end{array}$ & & & & & \\
\hline 9 - I liked it extremely & & & & & & \\
\hline $\begin{array}{l}\text { What is your opinion about the use } \\
\text { of this lawn in garden landscaping? } \\
\text { Please respond based on the numbers }\end{array}$ & & $\begin{array}{c}\text { Container } \\
11 \\
\end{array}$ & $\begin{array}{c}\text { Container } \\
12 \\
\end{array}$ & $\begin{array}{c}\text { Container } \\
13 \\
\end{array}$ & $\begin{array}{c}\text { Container } \\
14 \\
\end{array}$ & $\begin{array}{c}\text { Container } \\
15 \\
\end{array}$ \\
\hline below: & Appearance & & & & & \\
\hline 1 - I certainly wouldn't use & note: & & & & & \\
\hline $\begin{array}{l}2 \text { - Probably would not use } \\
3 \text { - I doubt if I would use }\end{array}$ & $\begin{array}{c}\text { Coloring } \\
\text { note: }\end{array}$ & & & & & \\
\hline $\begin{array}{l}4 \text { - I would probably use } \\
5 \text { - I would certainly use }\end{array}$ & $\begin{array}{l}\text { Use } \\
\text { note: }\end{array}$ & & & & & \\
\hline
\end{tabular}


The acceptability index (AI) was also evaluated, based on average grades obtained in the preference test. For the calculation, the following expression was adopted: $[\mathrm{AI}=$ $(\mathrm{Bx} 100) / \mathrm{C}]$. Where $\mathrm{B}$ is the average grade obtained for the product and $\mathrm{C}$ is the maximum grade given to the product.

To evaluate the intention of using the turfgrass in ornamenting garden landscaping, a 5-point structured scale was used (Chart 1), in which 5 represents the maximum score "certainly would use", and 1 represents the minimum score "certainly would not use" (Silva and Damásio, 1996)

The results of the evaluations were submitted through analysis of variance $\mathrm{F}$ and Tukey's test at the level of 5\% probability for comparison of means, using the SISVAR program for data analysis (Ferreira, 2019).

\section{Results and discussion}

The results demonstrate that there was a significant effect for the biometric evaluations carried out, where height and RCI were influenced by the use of the substrate or fertilization, while the DCGI was an interaction of the two factors (Table 2).

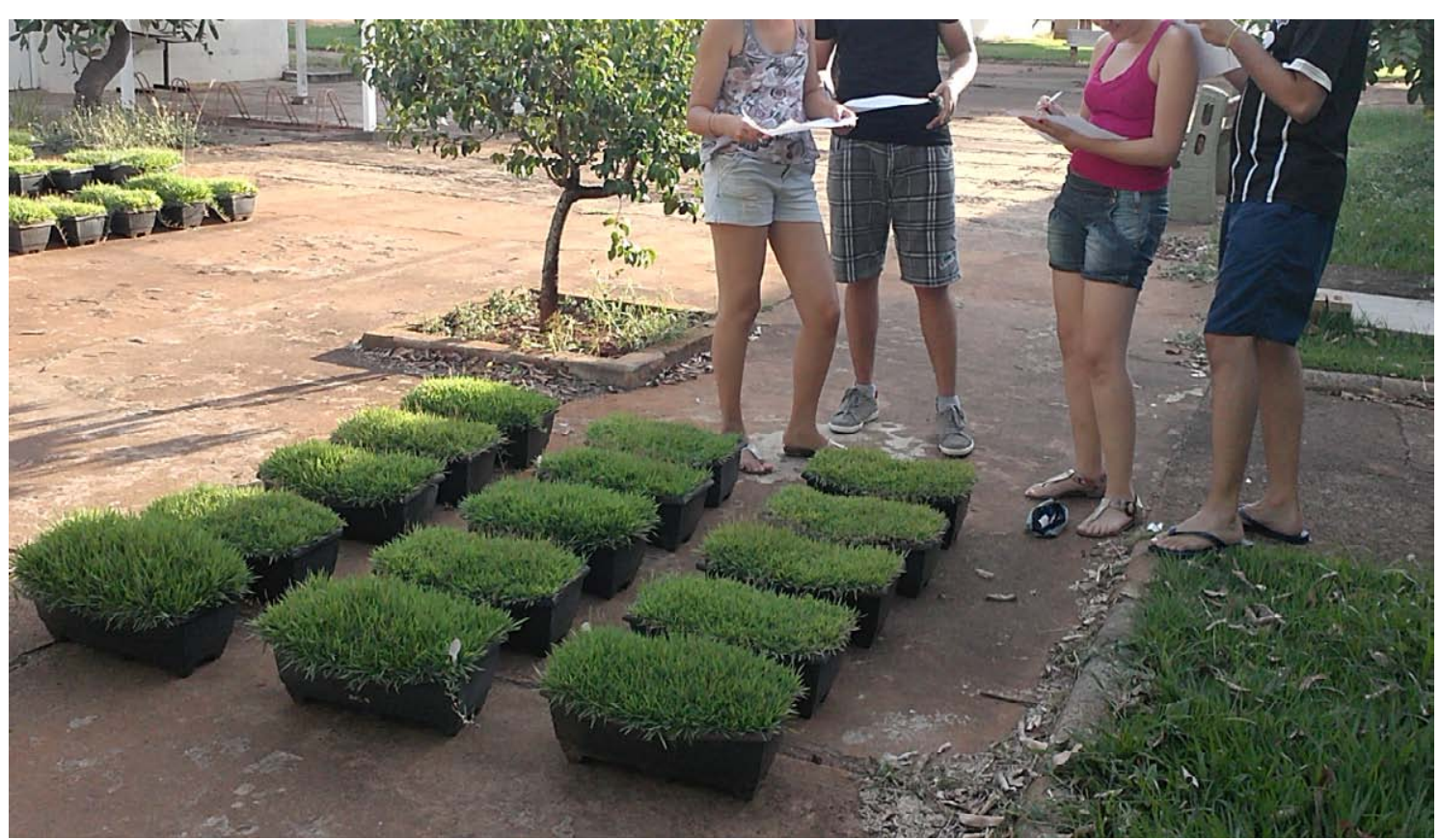

Figure 1. Sensory analysis test performed by untrained evaluators.

Table 2. Height, Chlorophyll Relative Index and Dark Green Color Index (DCGI) of Emerald grass grown on different substrates and mineral fertilization.

\begin{tabular}{|c|c|c|c|c|c|c|c|c|c|}
\hline \multirow[t]{2}{*}{ Subs } & \multicolumn{3}{|c|}{$\begin{array}{c}\text { Height } \\
\text { mm }\end{array}$} & \multicolumn{3}{|c|}{$\begin{array}{l}\text { CRI } \\
\text { CCI }\end{array}$} & \multicolumn{3}{|c|}{ DCGI } \\
\hline & C & A1 & A2 & $\mathbf{T}$ & A1 & A2 & $\mathbf{C}$ & A1 & A2 \\
\hline S1 & $31 \mathrm{cB}$ & $38 \mathrm{cA}$ & $40 \mathrm{cA}$ & $12.98 \mathrm{cdB}$ & $16.92 \mathrm{bcA}$ & $17.39 \mathrm{abA}$ & $0.24 \mathrm{~dB}$ & $0.31 \mathrm{dA}$ & $0.33 \mathrm{dA}$ \\
\hline S2 & $29 \mathrm{cB}$ & $34 \mathrm{dA}$ & $35 \mathrm{dA}$ & $11.47 \mathrm{~dB}$ & $15.78 \mathrm{cA}$ & $15.63 \mathrm{bA}$ & $0.25 \mathrm{~dB}$ & $0.33 \mathrm{dA}$ & $0.34 \mathrm{dA}$ \\
\hline S3 & $37 \mathrm{bB}$ & $42 \mathrm{bA}$ & $43 \mathrm{bA}$ & $14.67 \mathrm{bcB}$ & $18.85 \mathrm{abA}$ & $18.78 \mathrm{aA}$ & $0.36 \mathrm{cB}$ & $0.41 \mathrm{cA}$ & $0.42 \mathrm{cA}$ \\
\hline $\mathrm{S} 4$ & $36 \mathrm{bA}$ & $39 \mathrm{bcA}$ & $39 \mathrm{cA}$ & $16.48 \mathrm{abB}$ & $19.65 \mathrm{aA}$ & $18.70 \mathrm{aA}$ & $0.42 \mathrm{bB}$ & $0.44 \mathrm{bA}$ & $0.46 \mathrm{bA}$ \\
\hline S5 & $42 \mathrm{aB}$ & $48 \mathrm{aA}$ & $49 \mathrm{aA}$ & $18.07 \mathrm{aB}$ & $20.39 \mathrm{aA}$ & $19.57 \mathrm{aAB}$ & $0.46 \mathrm{aB}$ & $0.49 \mathrm{aA}$ & $0.50 \mathrm{aA}$ \\
\hline CV (\%) & \multicolumn{3}{|c|}{3.58} & \multicolumn{3}{|c|}{5.49} & \multicolumn{3}{|c|}{3.23} \\
\hline F substrate & \multicolumn{3}{|c|}{$120.592 * *$} & \multicolumn{3}{|c|}{$41.576^{* *}$} & \multicolumn{3}{|c|}{$398.319 * *$} \\
\hline F fertilization & \multicolumn{3}{|c|}{$84.563 * *$} & \multicolumn{3}{|c|}{$67.658 * *$} & \multicolumn{3}{|c|}{$119.232 * *$} \\
\hline F SxF & \multicolumn{3}{|c|}{$1.876^{\mathrm{ns}}$} & \multicolumn{3}{|c|}{$1.598^{\mathrm{ns}}$} & \multicolumn{3}{|c|}{$4.395^{* *}$} \\
\hline
\end{tabular}

Averages followed by the same lowercase letter in the column and uppercase in the row do not differ by Tukey's test at 5\% significance. S1- soil, S2- soil + sand (2:1), S3- soil + organic compost (1:1), S4- soil + organic compost + sand (2:1:1) and S5- organic compost + sand (3:1). C- Control, A1- 60 g $\mathrm{m}^{-2}$ NPK (10-10-10), A2-125 $\mathrm{g} \mathrm{m}^{-2}$ commercial product. 
For the height variable, the lowest results were observed by the control (without fertilization) in the substrates composed of soil and soil + sand (2: 1). The highest height was found in S5 fertilized with the commercial product. However, it is also noted that regardless of the fertilization carried out (A1 and A2), the results did not differ from each other, only in comparison with the control, thus showing the importance of correct fertilization management.

Still, this height increase found is due to the use of the substrate, where S5, based on organic compost + sand $(3: 1)$, presented the best results, regardless of the fertilization performed. According to Santos et al. (2019), substrates based on organic matter are able to retain more water and nutrients and thus increase the CEC and consequently the development of the turfgrass, providing greater increases in plant biomass. Experiments where substrates based on organic compost showed the best results have already been observed by Santos and Castilho (2015) in Emerald grass, Amaral et al. (2019) in bermuda grass (Cynodon spp.) and Dias et al. (2018) in carpet grass (Axonopus spp). Thus, after fertilization, S5 was able to provide large increases in height, mainly due to the greater availability of nitrogen.

In the two fertilizations performed, $\mathrm{N}$ was applied, which is the main nutrient required by turfgrass (Godoy et al., 2012), being A1 (10\%) and A2 (13\%). And so, greater amounts of $\mathrm{N}$ in the soil, greater plant growth occurs, since it is part of the main physiological processes of turfgrass (Gazola et al., 2016; Taiz et al., 2017). Nevertheless, greater growth of Emerald grass is not a desirable result for ornamental turfgrass, since there is an increase in costs to maintain the aesthetics of the plant, due to the intense mass production (Santos and Castilho, 2018a).

However, the values found in the present study are below those observed by Dinalli et al. (2015) (53 to 61 $\mathrm{mm}$ ), although, closer to those of Gazola et al. (2019) with an interval ranging from 31 to $55 \mathrm{~mm}$. Sampaio (2012) recommends for Emerald grass, height ranging from 20 to $40 \mathrm{~mm}$, so that the turfgrass aesthetics can be maintained, and thus all treatments of S5, and S3 fertilized with A1 and A2 are out of the above.

Likewise, as the substrates and fertilization influenced the height of the turfgrass, there was significance for the results of the CRI. Two substrates based on organic compost (S3, S4 and S5), managed to provide the highest values when fertilized with A1 and A2. This increase in CRI is due to the intense nitrogen fertilization, since chlorophylls are molecules derived from porphyrin, having $4 \mathrm{~N}$ atoms linked to one of $\mathrm{Mg}$ (Taiz et al., 2017). And thus, greater availability of the nutrient, there is a higher concentration of leaf chlorophyll.

Still, this higher concentration of RCI is essential for the physiological processes of the plant, since chlorophyll is responsible for producing energy for the turfgrass (Taiz et al., 2017), as well as providing intense green coloring (Santos et al., 2019 ), as reported by Santos and Castilho (2018b) in bermuda grass, and Gazola et al. (2016) in Emerald grass. And the DCGI results corroborate with the aforementioned, where the fertilizations performed (A1 and A2) managed to increase the color of the Emerald grass, when mainly grown in S5, thus having interaction between the factors

The fertilization A2 in the substrate S5, was the only treatment to present a result within the recommended by Godoy et al. (2012) for the species (0.50), thus inferring that the turfgrass is greener and aesthetically more acceptable. According to Gazola et al. (2016), it is essential that the Emerald grass after fertilization, present a turfgrass of intense green color, to be more aesthetically pleasing.

Even presenting different nutritional compositions, the two fertilizers showed similar results for the evaluated parameters, thus inferring that the use of the commercial product can be waste of fertilizer, when compared to the formulated. However, regardless of this, nutritional management is necessary.

For all evaluated variables (Table 2) the lowest results were found for S1 and S2, which are the treatments that do not contain organic compost, thus showing the importance of the ideal preparation of the substrate for better development of turfgrass areas.

Brazilian turfgrass are installed without having an ideal preparation of the land, mainly in clay soils, which end up hindering the development of the turfgrass, especially when it is not properly managed (Mateus et al., 2017; Santos e Castilho, 2018b). Therefore, the use of organic materials is essential to improve the development of the species (Santos and Castilho, 2015; Dias et al., 2018; Amaral et al., 2019; Santos et al., 2019).

Thus, when the turfgrass is cultivated in ideal conditions for its development, it has to be aesthetically pleasing and accepted by people, and sensory analysis can demonstrate this fact. 
Table 3. Frequency of acceptance, rejection and indifferent to the appearance and color attributes of Emerald grass grown on different substrates and mineral fertilization.

\begin{tabular}{|c|c|c|c|c|c|c|c|c|c|}
\hline & \multicolumn{3}{|c|}{ Acceptance* } & \multicolumn{3}{|c|}{ Indifferent** } & \multicolumn{3}{|c|}{ Rejection*** } \\
\hline \multicolumn{10}{|c|}{ Acceptance frequency for appearance $(\%)$} \\
\hline Substrate & $\mathbf{C}$ & A1 & A2 & $\mathbf{C}$ & A1 & A2 & $\mathbf{C}$ & A1 & $\mathbf{A 2}$ \\
\hline S1 & 63.01 & 73.22 & 92.03 & 18.26 & 14.64 & 5.43 & 18.72 & 12.13 & 2.54 \\
\hline S2 & 68.53 & 84.19 & 94.87 & 15.09 & 9.88 & 3.66 & 16.38 & 5.93 & 1.47 \\
\hline S3 & 81.05 & 93.55 & 93.56 & 12.10 & 3.58 & 5.08 & 6.85 & 2.87 & 1.36 \\
\hline S4 & 91.67 & 93.65 & 97.12 & 6.94 & 5.02 & 1.60 & 1.39 & 1.34 & 1.28 \\
\hline S5 & 96.74 & 98.43 & 98.49 & 3.26 & 1.57 & 1.51 & 0.00 & 0.00 & 0.00 \\
\hline \multicolumn{10}{|c|}{ Acceptance frequency for color $(\%)$} \\
\hline $\mathrm{S} 1$ & 41.49 & 77.37 & 89.51 & 26.60 & 12.35 & 7.49 & 31.91 & 10.29 & 3.00 \\
\hline $\mathrm{S} 2$ & 53.59 & 83.92 & 92.96 & 23.92 & 11.76 & 5.56 & 22.49 & 4.31 & 1.48 \\
\hline S3 & 66.38 & 94.66 & 91.84 & 19.40 & 5.34 & 6.80 & 14.22 & 0.00 & 1.36 \\
\hline S4 & 89.86 & 98.42 & 100.00 & 8.74 & 1.58 & 0.00 & 1.40 & 0.00 & 0.00 \\
\hline S5 & 93.36 & 100.00 & 100.00 & 6.64 & 0.00 & 0.00 & 0.00 & 0.00 & 0.00 \\
\hline
\end{tabular}

S1- soil, S2- soil + sand (2: 1), S3- soil + organic compost (1: 1), S4- soil + organic compost + sand (2:1:1) and S5- compost + sand (3:1). T - Control, A1 - $60 \mathrm{~g} \mathrm{~m}^{-2}$ NPK (10-10-10), A2 - $125 \mathrm{~g} \mathrm{~m}^{-2}$ commercial product. * Acceptance $=$ sum of the frequencies of grades 6 to 9 ; ** Indifferent $=$ frequency of grade $5 ; * *$ Rejection $=$ sum of the frequencies of grades 1 to 4 .

The results for sensory analysis demonstrate that for the frequency of acceptance and rejection of the appearance attribute, none of the treatments obtained $100 \%$ acceptance, however the results found were above $60 \%$, and both for rejection and for indifferent consumers the maximum values reached did not exceeded $19 \%$.

It is observed that the S5 treatment based on organic compound + sand (3: 1) was the one that obtained the highest frequency of acceptance, where the same substrate fertilized with the commercial product and NPK (10-1010) obtained the best grades consumers, respectively. It is noteworthy that S5 is the only substrate that does not present any frequency of rejection in the sensory test. For treatment S1 (without fertilization), the lowest frequency of acceptance was observed (63.01\%), which means that in relation to the rejection and indifferent frequencies, the substrate composed only of soil without fertilization, was the one that obtained the highest percentages, $18.72 \%$ and $18.26 \%$, respectively. However, the treatment did not reach extreme values to the point of not being accepted by consumers.

All the substrates that contained organic compost presented high frequencies, however, the treatments fertilized with the commercial product (A2) were the only ones to obtain percentages greater than $90 \%$. The substrates that did not undergo fertilization, had the lowest grades, compared to the fertilized treatments (A1 and A2). The low results provided by $\mathrm{S} 1$ and $\mathrm{S} 2$ without fertilization, of turfgrass development (Table 2), explain the lower acceptance rates of acceptance of said treatments (Table 3). Possibly, because the turfgrass had low height, CRI and little green color, it reflected in the consumer's choice.

S5, that showed high results of height (Table 2), evidenced great acceptance frequencies (Table 3), showing that regardless of the turfgrass being large, and its color can influence the choice of results, since this treatment presented high values of DCGI (Table 2), being more intense in color than the others. And so, acceptance by the color attribute, ended up being $100 \%$ in S5 fertilized with A1 and A2 (Table 3).

The S1 treatment without fertilization was the only substrate to obtain less than $50 \%$ acceptance by consumers, where only $41,49 \%$ of the evaluators liked the turfgrass, $26,60 \%$ were indifferent and 31.91\% rejected it. What proves these numbers are the low results of DCGI (Table 2). S2 without fertilization also showed a low DCGI result and, consequently, it was the second substrate that obtained the least acceptance with 53,59\% of frequency, the other treatments obtained percentages above $65 \%$, with their coloring greater than 0,31 .

According to Gazola et al. (2016), for ornamental turfgrass it is essential to have an intense green color and high density, and thus the acceptance of it by possible consumers will be greater, since the turfgrass will be more pleasing to the eye. When Emerald grass has low color values, it has a yellowish appearance (Godoy et al., 2012), which is not aesthetically acceptable and pleasant for people.

Amaral and Silva (2018) state that the objective of sensory evaluation is to detect diversity between products based on the perceived differences in the intensity of some attributes. Which occurred in the present study, as 
the treatments that contained more intense green (DCGI), obtained scores higher for the coloring attribute, since this aspect caught the attention of the evaluators, and possibly was more aesthetically accepted. Santos et al. (2018), state that color is one of the most important sensory attributes for the commercial acceptance of a product.

The averages assigned to the appearance and color attributes show that the substrate and fertilization are extremely important in the development of the turfgrass (Table 4) and directly influence the choice of the evaluators. The sensory scale that ranges from 1-9, can be similar to the turfgrass quality scale proposed by Morris and Shearman (1998), which also varies from 1 to 9, where 9 indicates a turfgrass of excellent quality, and 1 a turfgrass "dead". Scores of 6 or above are considered acceptable. Likewise, the authors classify the colors of the turfgrass from 1 to 9 , with 1 being light green, while 9, dark green. In the present study, the substrates fertilized with A1 and A2 showed values considered acceptable for both evaluated attributes, highlighting S5 with the highest results.

According to Morris and Shearman (1998) the evaluation of the quality of the turfgrass is generally a subjective process, through a visual classification system based on the judgment of the evaluator, where subjective measures of this type are always subject to criticism and concerns. However, the data from the sensory analysis corroborate with the development of the turfgrass (Table 2 ), showing that an adequate management provides good development of the species and reflects on the visual aspect and acceptance of evaluators. The same confirms Amaral and Silva (2018), who observed that the substrate is strictly related to the development of the plant and the acceptance of the product generated in the sensory evaluation.

Table 4. Average scores given for the appearance and color attributes of Emerald grass grown on different substrates and mineral fertilization.

\begin{tabular}{|c|c|c|c|c|c|c|}
\hline & \multicolumn{3}{|c|}{ Appearance } & \multicolumn{3}{c|}{ Color } \\
\hline Substrate & $\mathbf{C}$ & $\mathbf{A 1}$ & $\mathbf{A 2}$ & $\mathbf{C}$ & $\mathbf{A 1}$ & $\mathbf{A 2}$ \\
\hline S1 & 5.62 & 6.13 & 7.08 & 4.82 & 6.23 & 6.85 \\
\hline S2 & 5.95 & 6.49 & 7.00 & 5.36 & 6.54 & 6.92 \\
\hline S3 & 6.36 & 7.15 & 7.56 & 5.95 & 7.21 & 7.54 \\
\hline S4 & 7.38 & 7.67 & 8.03 & 7.33 & 8.10 & 8.18 \\
\hline S5 & 7.87 & 8.18 & 8.49 & 7.72 & 8.46 & 8.51 \\
\hline
\end{tabular}

S1- soil, S2- soil + sand (2:1), S3- soil + organic compost (1:1), S4- soil + organic compost + sand (2:1:1) and S5- organic compost + sand (3:1). CControl, A1 - $60 \mathrm{~g} \mathrm{~m}^{-2} \mathrm{NPK}(10-10-10), \mathrm{A} 2$ - $125 \mathrm{~g} \mathrm{~m}^{-2}$ commercial product.

The acceptability index of the turfgrass for the appearance attribute, showed that S5 fertilized A2 showed the highest value $(94.06 \%)$, not differing statistically between S2 and S4 fertilized with the same fertilizer, as well as it does not differ from A1. S1 and S2 without fertilization reported the lowest levels of acceptability, with $64.38 \%$ and $69.53 \%$ respectively, thus differing from the other treatments (Table 5). According to Chaves and Sproesser (2005), the frequency of acceptability must be greater than $70 \%$ for the product to be considered accepted by the evaluators, so that both treatments can be discarded. The other treatments showed values above those required by the authors, and they were accepted for the appearance attribute. These results confirm what Oliveira et al. (2018) that Emerald grass must be aesthetically pleasing to be used as an ornamental turfgrass and be in conditions of use in landscaping. Gazola et al. (2016) states that turfgrass with a more intense green color are more aesthetically accepted. 
Table 5. Acceptability Index for the appearance and color attributes of Emerald grass grown on different substrates and mineral fertilization

\begin{tabular}{|c|c|c|c|c|c|c|}
\hline \multicolumn{7}{|c|}{ Acceptability Index (\%) } \\
\hline \multirow[b]{2}{*}{ Subst. } & \multicolumn{3}{|c|}{ Appearance } & \multicolumn{3}{|c|}{ Color } \\
\hline & $\mathbf{C}$ & A1 & A2 & $\mathbf{C}$ & A1 & A2 \\
\hline S1 & $69.53 \mathrm{bB}$ & $73.62 \mathrm{cAB}$ & $77.99 \mathrm{cA}$ & $65.10 \mathrm{cB}$ & $74.87 \mathrm{bA}$ & $78.90 \mathrm{cA}$ \\
\hline $\mathrm{S} 2$ & $64.38 \mathrm{bB}$ & $78.15 \mathrm{bcA}$ & 85.88 abcA & $64.45 \mathrm{cB}$ & $80.20 \mathrm{bA}$ & $85.07 \mathrm{bcA}$ \\
\hline S3 & $82.12 \mathrm{aA}$ & $79.63 \mathrm{bcA}$ & 84.58 bcA & $72.90 \mathrm{bcB}$ & $80.56 \mathrm{bAB}$ & $85.69 \mathrm{abcA}$ \\
\hline $\mathrm{S} 4$ & $85.56 \mathrm{aA}$ & $85.14 \mathrm{abA}$ & $89.29 \mathrm{abA}$ & $81.48 \mathrm{abB}$ & $90.17 \mathrm{aA}$ & $90.96 \mathrm{abA}$ \\
\hline S5 & $88.57 \mathrm{aA}$ & $90.87 \mathrm{aA}$ & $94.06 \mathrm{aA}$ & $85.94 \mathrm{aB}$ & $93.92 \mathrm{aA}$ & $94.49 \mathrm{aA}$ \\
\hline CV (\%) & \multicolumn{3}{|c|}{6.92} & \multicolumn{3}{|c|}{6.26} \\
\hline F subs. & \multicolumn{3}{|c|}{$29.201 * *$} & \multicolumn{3}{|c|}{$30.940 * *$} \\
\hline F fert. & \multicolumn{3}{|c|}{$16.319 * *$} & \multicolumn{3}{|c|}{$32.461 * *$} \\
\hline F SxF & \multicolumn{3}{|c|}{$3.165^{* *}$} & \multicolumn{3}{|c|}{$0.581^{\mathrm{ns}}$} \\
\hline
\end{tabular}

Averages followed by the same lowercase letter in the column and uppercase in the row do not differ by Tukey's test at $5 \%$ significance. S1- soil, S2- soil + sand (2:1), S3- soil + organic compost (1:1), S4- soil + organic compost + sand (2:1:1) and S5- organic compost + sand (3:1). C- Control, A1 - 60 g $\mathrm{m}^{-2}$ NPK (10-10-10), A2 -125 $\mathrm{g} \mathrm{m}^{-2}$ commercial product.

And so, with respect to the color attribute, S1 and S2 without fertilization also showed less than $70 \%$ frequency, not being accepted by the evaluators, and being discarded (Chaves and Sproesser, 2005). S5 fertilized with A2, showed the highest acceptability ( $94.49 \%)$, being statistically equal to S3 and S4 fertilized with the same fertilizer, and S5 fertilized with NPK (10-10-10). The other treatments show rates above $72 \%$ for the color of the turfgrass, so all these treatments are considered accepted by the evaluators.

Santos et al. (2018) say that the acceptability of the product is differentiated by the sex and age attribute, where both are relevant intervening factors of the consumer's characteristics, since they are believed to be the most discerning women for sensory tests. However, in the present study, the gender preference of each attribute was not discriminated, showing that in a future more careful analysis, differences between men and women may occur.

\section{Conclusions}

Substrates based on organic compost showed the best results for the evaluated parameters, being recommended its use in the cultivation of Emerald grass. The fertilizations carried out with the commercial product and the formulated NPK (10-10-10), presented similar results in the turfgrass development evaluations. Sensory evaluation is an important tool for ornamental and aesthetic acceptance of a turfgrass, clearly showing that correct handling of the grass, reflects the acceptance of the evaluators who were judicious in their choice, based mainly on the green color.

\section{Author contribution}

P.L.F.S.: Idea of the experiment, field analysis, analysis and interpretation of data, critical review. P.S.T.S.: Field analysis, data collection and analysis, translation. A.M.S.M.: Field analysis, data collection, analysis. M.L.A.: Field analysis, data collection and analysis. M.V.L.N.: Critical review, analysis, and interpretation of data. R.M.M.C.: Critical review, analysis and interpretation of data, approval of the final version, work advisor.

\section{References}

AMARAL, J.A.D.; PAGLIARINI, M.K.; HAGA, K.I.; CASTILHO, R.M.M. Luminosity levels and substrates composition on bermuda grass development. Ornamental Horticulture, v.25, n.2, p.168-179, 2019. DOI: http:// dx.doi.org/10.14295/oh.v25i2.1454

AMARAL, M.T.; SILVA, V.N. Casca de arroz carbonizada para produção de flores comestíveis de amor-perfeito. Revista Brasileira de Tecnologia Agropecuária, v.2, n.1, p.11-17, 2018.

BACKES, C.; SANTOS, A.J.M.; GODOY, L.J.G.; VILLAS BOAS, R.; BESSA, S.V. Efeito residual do lodo de esgoto e de manejos mecanizados na produção de tapetes e na extração de nutrientes pela grama esmeralda. Espacios, v.38, n.14, p.03, 2017.

CHAVES, J.B.P.; SPROESSER, R.L. Práticas de laboratório de análise sensorial de alimentos e bebidas. Viçosa: UFV, 2005. 81p.

\section{CHRISTIANS, N.E.;PATTON,A.J.;LAW,Q.D.Fundamentals of Turfgrass Management, 5ed. Wiley:Ames, 2016. 480p.}

DIAS, J.A.C.; SANTOS, P.L.F.; GAZOLA, R.P.D.; SARAIVA, B.C.; CASTILHO, R.M.M. Substrates and fertilization in the development of São Carlos grass. Scientific Electronic Archives, v.11, n.6, p.26-31, 2018. DOI: http://dx.doi.org/10.36560/1162018587 
DINALLI, R.P.; BUZETTI, S.; GAZOLA, R.N.; CASTILHO, R.M.M.; CELESTRINO, T. S.; DUPAS, E.; TEIXEIRA FILHO, M. C. M.; LIMA, R. C. Doses de nitrogênio e aplicação de herbicidas como reguladores de crescimento em grama esmeralda. Semina: Ciências Agrárias, v.36, n.3, supl.1, p.1875-1894, 2015. DOI: http:// dx.doi.org/10.5433/1679-0359.2015v36n3Supl1p1875

FERREIRA, D.F. SISVAR: A computer analysis system to fixed effects Split plot type designs. Revista Brasileira de Biometria, v.37, n.4, p.529-535, 2019. DOI: https://doi. org/10.28951/rbb.v37i4.450

GAZOLA, R.P.D.; BUZETTI, S.; GAZOLA, R.N.; CASTILHO, R.M.M.; TEIXEIRA FILHO, M. C. M.; CELESTRINO, T. S.; DUPAS, E. Nitrogen dose and type of herbicide used for growth regulation on the green coloration intensity of Emerald grass. Ciência Rural, v.46, n.6, p.984-990, 2016. DOI: http://dx.doi.org/10.1590/0103$8478 \mathrm{cr} 20150276$

GAZOLA, R.P.D.; BUZETTI, S.; GAZOLA, R.N.; CASTILHO, R.M.M.; TEIXEIRA FILHO, M.C.M.; CELESTRINO, T.S. Nitrogen fertilization and glyphosate doses as growth regulators in Esmeralda grass. Revista Brasileira de Engenharia Agrícola e Ambiental, v.23, n.12, p.930-936, 2019. DOI: https://doi.org/10.1590/18071929/agriambi.v23n12p930-936

GODOY, L.J.G.; VILLAS BÔAS, R.L.; BACKES, C.; SANTOS, A.J.M. Nutrição, Adubação e Calagem para produção de gramas. Botucatu: FEPAF, 2012. 146p.

KARCHER, D.E.; RICHARDSON, M.D. Quantifying turfgrass color using digital image analysis. Crop Science, v.43, p.943-951, 2003. DOI: https://doi.org/10.2135/ cropsci2003.9430

MORRIS, K.; SHEARMAN, R. NTEP turfgrass evaluation guidelines. In: NTEP Turfgrass Evaluation Wkshp. Natl. Beltsville: Turfgrass Evaluation Program, 1998. p.1-5.

MOTA, F.D.; VILLAS BÔAS, R.L.; MATEUS, C.M. D.; SILVA, T.B.G. Sewage sludge compost in zoysia grass sod production. Revista Ambiente \& Água, v.14, n.1, e2301, 2019. DOI: https://doi.org/10.4136/ambi-agua.2301

NEVES, A.L.R.; LACCERDA, C.F.; OLIVEIRA, A.C.; SOUZA, C.H.C.; OLIVEIRA, F.I. F.; RIBEIRO, M.S.S. Quantitative and qualitative responses of Catharanthus roseus to salinity and biofertilizer. Revista Brasileira de Engenharia Agrícola e Ambiental, v.22, n.1, p.22-26, 2018. DOI: https://doi.org/10.1590/1807-1929/agriambi. v22n1p22-26
OLIVEIRA, N.B.; OLIVEIRA, J.F.V.; SANTOS, P.L.F.; GAZOLA, R.P.D.; CASTILHO, R.M.M. Avaliação do estado nutricional de três gramados ornamentais em Ilha Solteira-SP: um estudo de caso. Revista LABVERDE, v.9, n.1, p.96-119, 2018. DOI: http://dx.doi.org/10.11606/ issn.2179-2275.v9i1p96-119

SAMPAIO, H.A. Manutenção em gramados ornamentais. In: BACKES, C.; GODOY, L.J.G.; MATEUS, C.M.D.; SANTOS, A.J.M.; VILLAS BÔAS, R.L.; OLIVEIRA, M.R. Tópicos atuais em gramados III. Botucatu: FEPAF, 2012. p.192-200.

MATEUS, C.M.D.; TAVARES, A.R.T.; OLIVEIRA, M.R.; JACON, C.P.R.P.; SARTORI, M.M.P.; FERNANDES, D.M.; VILLAS-BÔAS, R.L. Influence of substrate base on sports field covered with bermuda grass. Ornamental Horticulture, v.23, n.3, p.319-328, 2017. DOI: https://doi. org/10.14295/oh.v23i3.1104

SANTOS, P.L.F.; CASTILHO, R.M.M. Relação entre teor de clorofila e nitrogênio foliar em grama esmeralda cultivada em substratos. Tecnologia \& Ciência Agropecuária, v.9, n.2, p.51-54, 2015.

SANTOS, P.L.F.; CASTILHO, R.M.M. Resposta da grama esmeralda em função de diferentes fertilizantes e substratos. Cultura Agronômica, v.27, n.3, p.354-365, 2018a. DOI: https://doi.org/10.32929/2446-8355.2018v27n3p354-365

SANTOS, P.L.F.; CASTILHO, R.M.M. Substrates in the development of a sports turfgrass "Tifton 419". Ornamental Horticulture, v.24, n.4, p.138-144, 2018 b. DOI: https://doi.org/10.14295/oh.v24i2.1155

SANTOS, P.L.F.; CASTILHO, R.M.M.; GAZOLA, R.P.D. Pigmentos fotossintéticos e sua correlação com nitrogênio e magnésio foliar em grama bermuda cultivada em substratos. Acta Iguazu, v.8, n.1, p. 92-101, 2019.

SANTOS, P.L.F.; REIS, H.P.G.; FRIGÉRIO, G.C.; NARDY, H.D.; SANTOS, M.C.G. Aceitabilidade de diferentes composições de calda de compota de figo para ambos os sexos. In: MAGNONI JUNIOR, L.; SILVA JUNIOR, E.C.; TONDATO, C.; COLOMBO, A.S.; SILVA, A.P.; TONIN, G.A.; BRANCO JUNIOR, G.A.; MAGNONI, M.G.N.; FIGUEIREDO, W.S. (Org). Mobilizar o conhecimento para alimentar o Brasil. São Paulo: Centro Paulo Souza, 2018. p.496-506.

SILVA, M.A.A.; DAMÁSIO, M.H. Análise sensorial descritiva. Campinas: Universidade Estadual de Campinas, 1996. 60p.

TAIZ, L.; ZEIGER, E.; MÜLLER, I.M.; MURPHY, A. Fisiologia e desenvolvimento vegetal. 6ed. Porto Alegre: Artmed, 2017. 858p. 